\title{
INVESTICIJŲ I AUKŠTĄJĮ IŠSILAVINIMĄ IR VALSTYBĖS PAJAMŲ BEI IŠLAIDŲ PRIKLAUSOMYBĖS TYRIMAS
}

\author{
Vilda Gižiené ${ }^{1}$, Aldona Markauskienè $\dot{2}^{2}$ \\ ${ }^{I}$ Kauno technologijos universitetas, Lietuva, vilda.giziene@ktu.lt \\ ${ }^{2}$ Kauno technologijos universitetas, Lietuva, aldona.markauskiene@ktu.lt \\ crossref http://dx.doi.org/10.5755/j01.em.17.3.2135
}

\begin{abstract}
History of human development confirms the close relationship between education and economic development. Successful economic development is increasingly dependent on the investment in higher education. Examining the education and professional training, the researchers focused on three key issues: the economic value of education and professional training in individual enterprises analysis; higher education and the revenue relationship structure analysis; and preparation of the optimal strategy for human resources development.

Investment in higher education efficiency is dependent on external and internal factors. Internal effects - individual competencies, skills, and everything depending on the individual; external - environment for the investment process. External effects are treated as social or public benefits.

The country's investment in human resources is measured by the share of the national product used for the education and science. In order to determine the economic efficiency of the investment in higher education, it is necessary to compare the expenditures (costs) and results (benefits).

The goal of the article is to evaluate the investment in higher education from the point of view of the State. The object of the article is the investment in higher education. The article uses evaluation methods of statistical processing. The method selection was determined by data accessibility.

For evaluation of investment in higher education from the point of view of the State, the analysis used the short-term return rate and the "brain drain" methods. The estimated State investment's in higher education short-term rate of return (ROR) has shown that RORstate (university education)> RORstate (college education) (15.55\%> 3.96\%). This suggests that it is more beneficial for the State to subsidize university education than college education. The greatest negative impact on the process of State investment in higher education is caused by the "brain drain". This impact is evaluated taking into consideration the following indicators: the amount of State spending per student in higher education level; overall number of First Degree (BA) and college graduates; and the number of individuals with higher education degree who have emigrated.

The analysis of the positive and negative effects of investments in higher education and their impact on the state, concludes that primarily responsible for the studies must be the individual (the investor), and the State has to only cooperate. To ensure the accessibility of studies, socially disadvantaged students should be funded. In order to make education accessible to everyone, student loan funding system should be functional.

Keywords: high education, investments, human capital

JEL Classification: I23, I25, J24.
\end{abstract}

\section{Ivadas}

Išsilavinimas yra vienas iš svarbiausių šiuolaikinès žinių ekonomikos plètros veiksnių. Individo žinios ir gebejjimai gali būti apibrěžti kaip nematerialus kapitalas. Visi individai siekia pakelti savo žmogiškojo kapitalo akcijas, tam didelę įtaką daro išsilavinimas. Investicijos į žmogų didina produktyvumą. Švietimo ir mokslo sričių vystymuisi reikalingos ilgalaikès ir didelès investicijos. Šias investicijas būtina ịvertinti socialiniu aspektu. Baier ir kt., 2006; Becker, 1964; Haveman, Bershadker, Schwabish, 2003; Kendrick, 1976; Mankiw, Romer, Weil, 1992; Mincer, 1958, 1962, 1974; Schultz, 1971; Globerman, Shapiro, 2002; Noorbakhsh, Paloni, Youssef, 2001, Wahrenburg, Weldi, 2007, Psacharopoulos, 1995, Mincer, 1974, Daugeliene \& Marcinkeviciene, 2009, Bagdanavičius, 2009, Cekanavicius \& Kasnauskiene, 2009, Kazlauskaite \& Buciuniene, 2008; Liepe \& Sakalas, 2008; Melnikas, 2008; Sedziuviene \& Vveinhardt, 2009 ivvairiais požiūriais analizuoja žmogiškojo kapitalo sampratą, investicijas i žmogiškaji kapitalą (investicijos i aukštaji išsilavinimą yra svarbiausia žmogiškojo kapitalo vertinimo dalis), jų efektyvumą ir atsiperkamumą.

Svarbu įvertinti investicijų $\mathfrak{i}$ aukštaji išsilavinimą efektyvumą, nustatyti laiko santyki ir paklaida, pinigu srautus: iplaukas, išlaidas; Didelès lèšos skiriamos aukštajam mokslui, protai nuteka, todèl svarbu vertinti naudą ne tik individui, bet ir valstybei. Šiu dienu ekonomikoje vis labiau vertinami nematerialūs ištekliai, kuo darbuotojai turi daugiau patirties, igūdžiug, aukštesni išsilavinima, tuo labiau keliama organizacijos vertė (Makštutis, 2007). Žmogiškojo kapitalo praradimas dèl migracijos daro neigiamą itaką šalies ekonomikos augimui.

Tyrimo problema - kai ịvertinti investicijas į aukštaji išsilavinimą valstybės požiūriu.

Tyrimo tikslas - iqvertinti investicijas į aukštaji išsilavinimą valstybės požiūriu. 
Tyrimo objektas - investicijos i aukštaji išsilavinimą.

Tyrimo uždaviniai:

1. Išanalizuoti investiciju i aukštaji išsilavinimą valstybès požiūriu vertinimo metodiką.

2. Atlikti investicijų i aukštaji išsilavinimą vertinimo tyrimą Lietuvoje.

\section{Investicijų $\mathfrak{i}$ aukštąjį išsilavinimą vertinimo valstybès požiūriu metodika}

Žmonijos vystymosi istorija patvirtina glaudų ryši tarp švietimo ir ekonomikos išsivystymo lygiụ. Sèkmingas ekonomikos vystymas vis daugiau priklauso nuo to, kokios bus investicijos i aukštaji išsilavinimą. Tiriant išsilavinimą ir profesini parengima, tyrëjai daugiausiai dèmesio skyrè trims pagrindinèms problemoms: išsilavinimo ekonominès vertès ir profesinio parengimo atskirose i̇monèse tyrimui: igyto aukštojo išsilavinimo ir gaunamu pajamų ryšiu struktūros tyrimui ir žmogiškujų ištekliu išsivystymo optimalios strategijos parengimui.

A. Šileikos ir Z. Tamašauskienès teigimu (2003), sudètinga ỉvertinti teigiamą investicijų i aukštaji išsilavinimą poveiki ekonomikos augimui. Darbo užmokesčio skirtumai gali nerodyti visuomeninès išsilavinimo naudos. Investiciju $\mathfrak{i}$ aukštaji išsilavinimą efektyvumą lemia išoriniai ir vidiniai poveikiai. Vidiniai poveikiai - individo kompetencijos, gebejjimai ir visa kas priklauso nuo individo; išoriniai - aplinka, kurioje vykta investicinis procesas. Išoriniai poveikiai yra traktuojami kaip socialinė arba visuomeninė nauda. Efektyvumą, išreiškiamą išoriniu poveikiu visuomenei, analizuoja W. W. McMahon (Johnes, Johnes, 2004). Išorinis investicijų i žmogiškaji kapitalą poveikis analizuojamas kaip išsilavinimo itaka specifiniams tikslams pasiekti, kurie savo ruožtu lemia ekonomikos augimą ir vystymosi perspektyvas. Autoriaus akcentuojamas investicijų i švietimą ilgalaikis efektas. W.W. McMahon išskiria keletą tikslų, kurių igyvendinimas per aukštojo išsilavinimo daromą teigiamą įtaką lemia bendrojo vidaus produkto, tenkančio vienam gyventojui, darbo užmokesčio dydị: ittaka sveikatai, pasireiškianti mažesniu mirtingumo lygiu, gyventojų ilgaamžiškumu, bendru visuomenès sveikatos lygiu. Taip pat investicijų i aukštaji išsilavinimą efektyvumas nustatomas nusikalstamumo lygio sumažèjimu, skurdo ir socialinės atskirties mažinimu sukurtu technologijų vystymu bei mokslinių tyrimų skaičiumi. Fiskaliniu požiūriu investicijos į švietimą daro didelę ittaką mokestinėms pajamoms. Aukštesnis išsilavinimo lygis, L. Wößmann ir G. Schütz (2006) teigimu, didina darbo užmokestị, kartu didẻja mokesčiai ir valstybės pajamos. Mokestinès pajamos sudaro valstybès biudžeto dali, todèl daro teigiamą poveiki visuomenei.

Investicijos i aukštaji išsilavinimą yra pažangiausias individo gyvenimo kokybès gerinimo būdas, suteikiantis jam daugiau gebejjimų ir galimybių efektyviai savirealizacijai. Todèl šalies švietimo sistema turi didelę reikšmę vertinant individą kaip atskirą socialini vienetą ir kaip šalies ekonominio potencialo vystymo veiksni (Hazelkorn, Huisman, 2008). Studijų sèkmè teigiamai sąlygoja verslumo didinimą žinių ekonomikos sąlygomis (Schultz, 1998). Ttuo paaiškinama ir individo iniciatyva siekti aukštojo. Besikeičiančios darbo rinkos tendencijos, kur nuolatos auganti aukštos kvalifikacijos specialistų paklausa ir mažejantis nekvalifikuotos darbo jègos poreikis, lemia pačiu individų apsisprendimą investuoti i išsilavinimą.

Valstybès investicijos į žmogiškajj kapitalą vertinamos pagal sukurto nacionalinio produkto dali, skirtą švietimui ir mokslui. Norint nustatyti investicijų $\mathfrak{i}$ aukštaji išsilavinimą ekonomini efektyvumą, būtina palyginti išlaidas (sąnaudas) ir rezultatus (naudą). Investicijų i aukštajj išsilavinimą ekonominio efektyvumo nustatymas apima tris nuoseklius etapus:

1. Išlaidų struktūros nustatymą ir įvertinimą;

2. Gaunamos naudos struktūros nustatymą ir jos ịvertinimą;

3. Išlaidų ir rezultatų palyginimą.

Valstybės ekonominè nauda, dèl investicijų i aukštaji išsilavinimą apibrèžiama:

- ekonomikos augimu. Investicijos i žmogiškaji kapitalą - svarbiausias vidaus ekonomikos augimo veiksnys. Ivairių pasaulio šalių mokslininkai nustatè, kad egzistuoja tiesioginis ryšys tarp investiciju $\mathfrak{i}$ išsilavinimą ir ekonomikos augimo. Denison, aiškindamas ekonomikos augimo veiksnius, nustatè, kad 60 proc. individo pragyvenimo pajamu sukuria išsilavinimas ir kad išsilavinimas 30 proc. pakelia darbo kokybę (Seniūnaitè, 2002). Remiantis pasaulinio lygio ekonomikos specialistu tyrimais Europos komisijos veikale (European Commission, 2005) konstatuojama, kad darbo kokybè dèl individų igyjamo aukštojo išsilavinimo padidina metini BVP 0,5 proc. Nustatyta, kad mažiau išsivysčiusiose šalyse vyrauja žemesnio lygio individu išsilavinimas. Išsivysčiusiose šalyse vyrauja didesnè aukštesniji išsilavinimą turinčių asmenų paklausa (Mingat, Tan, 1996). 
- Mokestinemis pajamomis, t.y. i valstybės biudžetą patenka daugiau mokestiniu pajamų iš aukštaji išsilavinimą turinčių asmenų ir dirbančių geriau apmokamą darbą.

- Papildomomis pajamomis - kai išvengiama didelio bedarbių skaičiaus ir sutaupoma socialiniu pašalpų sąskaita.

Kitas labai svarbus veiksnys, kuris turi itakos investicijoms į aukštaji išsilavinimą valstybės požiūriu emigracija. Lietuvai tapus Europos Sajungos nare ir pradejjus glaudžiau issilieti i bendrą ekonominę ir socialinę erdvę, ịvairūs išoriniai veiksniai daro ittaką vidaus ekonominei, socialinei ir politinei šalies aplinkai. Remiantis A. Sipavičiene (2006), per pastaruosius 10-15 metu Lietuvoje ivyko keli migracijos srautai, pasižymintys skirtingais tikslais, kryptimis ir strategijomis. Ivertinus šiuos skirtumus nustatomi migracijos modeliai:

Komercinès migracijos modelis. Pagrindinè šio modelio funkcija - žvalgybinè, tai - migracijos inicijavimo ir pirminio kapitalo kaupimo priemonè. Šis modelis, dominavo XX a. dešimtojo dešimtmečio pradžioje ir šiuo metu virto kita migracijos forma, t.y. darbo migracija arba emigracija.

Darbo migracijos modelis šiuo metu tapęs dominuojančiu, tačiau pakitęs, lyginant su pradiniu migracijos etapu. Trumpalaike nelegalaus darbo migracija virsta ilgalaike, darbas užsienyje vis dažniau igauna legalų pobūdị.

Mokslo migracija. Pirminiame dabartinių migracijos tendencijų etape mokslo migracija ne tiek atliko mokymo / kvalifikacijos kèlimo funkcija, kiek buvo kanalas patekti į užsieni. Šiuo metu mokslo migracija iš tiesų pradeda atlikti savo tiesioginę funkciją ir tampa žinių ar profesijos siekimo strategija.

„Protų nutekẻjimo“ modelis. Šio migracijos modelio mastas ypač didelis ir igaunantis kitokị pobūdi, nes jei anksčiau išvykę kvalifikuoti specialistai dirbo nekvalifikuotus darbus ir ne pagal specialybę, t. y. vyko vadinamasis protu švaistymas, tai šiuo metu daugeja specialistu, kurie išvykę dirba pagal savo turimą specializaciją.

Šeimų susijungimo modelis. Šis modelis pasireiškia laikinai migracijai virstant emigracija, t. y. prie migrantu, įsikūrusių užsienyje, prisijungia kiti šeimos nariai, giminès ar draugai.

Ekonominè emigracija tai - išvykimas iš Lietuvos isikurti užsienio valstybeje siekiant geresnès gyvenimo kokybės, didesnio darbo užmokesčio, geresnių darbo ir gyvenimo sąlygų, ar dėl kitų ekonominių priežasčių. Kalbant apie ekonominę migracija, dažnai pasitelkiamas ir „protų nutekẻjimo“ terminas. Siauraja prasme protų nutekejimu dažnai vadinama mokslininkų ir tyrëjų emigracija. Tačiau dažnai šis terminas turi ir platesnę prasmę: t.y., aukštą kvalifikaciją turinčių darbuotojų išvykimas dirbti i̇ užsienį. Kartais ekonominès migracijos ir protų nutekejjimo terminai yra supriešinami vienas kitam darant prielaidą, kad ekonominius migrantus išvykti skatina išimtinai ekonominès priežastys (pirmiausia, nedarbas). Tuo tarpu aukštos kvalifikacijos asmenų motyvai gali būti daug platesni: karjeros galimybès, darbas tarptautinèje aplinkoje, bendri tyrimai, prestižas ir kt. Pastaruoju atveju galima kalbėti ir apie „,protų cirkuliaciją“, kuri vyktų, jei išvykusieji igytų žinių, patirties, pasisemtų Vakarų kultūros ir sugrị̌tų (nemažai valstybių netgi skatina tokią cirkuliacija). Vis dėlto, Lietuvos kontekste apie protų nutekèjimą galima kalbèti kaip vieną iš ekonominès migracijos tipų, kadangi išvykstama daugiausia dèl ekonominių priežasčių. Ypač tai būdinga aukštos kvalifikacijos asmenims, kurie dirbo valstybės finansuojamose srityse (mokslininkai, gydytojai, mokytojai). Dažnai tokie asmenys užsienyje dirba gerai apmokamus, tačiau žemesnès kvalifikacijos reikalaujančius darbus. Tokiu atveju kalbama apie „protų švaistymą“. Sparčiai emigruojant Lietuvos gyventojams, šalyje susiduriama su darbo jègos trūkumu. Taigi, vertinant investicijas i aukštaji išsilavinima, būtina įvertinti emigracijos masto poveikị.

Beveik 50 proc. studentu (remiantis statistikos departamento prie LR Vyriausybès duomenimis) aukštojo išsilavinimo studiju kainą subsidijuoja valstybė. Esminė problema šiuo atveju yra ta, kad sunku ịvardinti socialinius kriterijus (pagal kuriuos turètų būti atrenkami individai, kuriems mokslas būtu kompensuojamas) ir paramos dydị. Investicijų i aukštaji išsilavinimą poveikis valstybei vertinamas dviem būdais: 1) ịvertinant valstybès investicijų i aukštaji išsilavinimą teigiamą poveiki (nauda); ir 2) ỉvertinant šių investicijų neigiamą poveiki (nuostoli).

Apibendrinant išskirtus metodus valstybės investicijoms i aukštaji išsilavinimą vertinti galima daryti išvadą, kad rezultatas gali būti teigiamas ir neigiamas. Teigiamą šių investicijų poveikį siūloma vertinti pasinaudojus Psacharopoulos (1995) sukurtu trumpalaikio periodo metodu ir ji adaptavus Lietuvai. Vertinant investicijų efektyvumą (teigiamą poveiki) vertinami šie rodikliai: studijų trukmè (pasirenkama 4 metai), darbo užmokestis individui, igijusiam aukštaji išsilavinima, darbo užmokestis individui, igijusiam tik vidurini išsilavinimą ir valstybès išlaidos (subsidijos) aukštajam mokslui. Kuo apskaičiuota investiciju grąžos norma valstybei (RORvalstybès) yra didesné, tuo valstybès investicijos $\mathfrak{i}$ aukštaji mokslą yra 
efektyvesnès. Valstybės investicijų $\mathfrak{i}$ aukštaji mokslą teigiamo poveikio vertinimui naudotinas Psacharopoulos (1995) trumpalaikio periodo modelis:

$$
\text { RORvalstybès }=\frac{\overline{\mathrm{W}}_{\mathrm{u}}-\overline{\mathrm{W}}_{\mathrm{s}}}{4\left(\overline{\mathrm{W}}_{\mathrm{s}}+\overline{\mathrm{C}}_{\mathrm{u}}\right)}
$$

čia:

$\mathrm{W}_{\mathrm{u}}$ - darbo užmokestis igijus aukštaji išsilavinima;

$\mathrm{W}_{\mathrm{s}}$ - darbo užmokestis neigijus aukštojo išsilavinimo;

$\mathrm{C}_{\mathrm{u}}-$ valstybès išlaidos (subsidijos) aukštajam išsilavinimui igyti.

Galima išskirti teigiamus investicijų i aukštaji išsilavinimą poveikius valstybei:

- Didesnès mokestinès pajamos dèl darbo užmokesčio padidejjimo igijus aukštaji išsilavinimą;

- Individų sveikatos gerèjimas: išsilavinę individai labiau rūpinasi savo sveikata;

- Nusikalstamumo mažejjimas;

Vertinant valstybės investicijų i aukštaji išsilavinimą neigiamą poveiki (nuostolius) būtina ịvertinti proto nutekejjimo problemą ir protu švaistymo. Protų švaistymas yra, kai individai igyja netinkamą išsilavinimą ir jo nepanaudoja - dirba darbus, neatitinkančius jo kvalifikacijos.

Didžiausią neigiamą poveiki valstybės investicijų $\mathfrak{i}$ aukštaji išsilavinimą procese daro „protų nutekejjimas“. Ši poveikị siūloma vertinti, ivertinant tokius rodiklius: valstybès skiriamų lèšu vienam studentui aukštojo mokslo studijoms dydị, visų baigusiujų aukštają mokyklą skaičių I pakopos (bakalauro) ir kolegines studijas; emigravusių individų su aukštuoju išsilavinimu skaičių. Nuostolis paskaičiuojamas sekančiai:

1. apskaičiuojama, kokią sumą valstybė skyrė lèšų visiems individams, einamaisiais metais, igijusiems aukštaji išsilavinimą;

2. ivvertinamas individų, igijusių aukštaji išsilavinimą ir emigravusių skaičius;

3. daroma prielaida, kad emigravę individai su aukštuoju išsilavinimu studijavo valstybès subsidijuojamose vietose;

4. apskaičiuojama valstybės nuostolis dèl „protu nutekëjimo“. Individai, igiję aukštaji išsilavinima, pasinaudoję valstybès parama (mokinosi valstybinèse vietose) ir emigravę iš Lietuvos daro neigiamą poveiki ekonomikos augimui: valstybès lèšos investuojamos neefektyviai ir neatsiperka, nes tokie individai nedirba Lietuvoje, nemoka mokesčių.

Ivertinus investicijų $i$ aukštaji išsilavinimą teigiamą ir neigiamą poveikị valstybei darytina išvada, kad už savo studijas pirmiausia turi būti atsakingas pats asmuo (investuotojas), o valstybè gali tik prisidèti. Norint užtikrinti studijų prieinamumą turètų būti finansuojami socialiai remtini studentai. Siekiant, kad išsilavinimas būtų prieinamas visiems turètų veikti studijų paskolų finansavimo sistema.

\section{Investicijų i aukštąji išsilavinimą tyrimas Lietuvoje}

Ekonomikos augimas užima pagrindinę vietą makroekonomikos teorijoje. Pagrindinis bendras ekonomikos augimą skatinančių veiksnių tyrimų bruožas yra tai, kad žmogiškasis kapitalas yra atskirtas nuo fizinio kapitalo. Svarbią reikšmę ekonomikos augimui turi moksliniai tyrimai, individu igytas išsilavinimas. Visa tai apima žmogiškaji kapitala. Kiekvienos šalies ekonomine gerove priklauso nuo jos gyventoju pajamų, t.y., kokios yra šeimų pajamos, kokie yra tos šalies gyventojų prioritetai, o taip pat ir nuo individų gabumų.

Aukštasis mokslas neabejotinai naudingas konkrečiam individui - ir tam, kuris pats moka už studijas, ir tam, už kurio studijas sumoka valstybè (kitu atveju niekas neinvestuotu i aukštaji išsilavinima). Individai, igiję aukštaji išsilavinima, uždirba daugiau, ir tai daugeli paskatina investuoti i savo pačių žinias. Aukštojo mokslo kainą gali padengti pats studentas (iš savo sutaupytų, tẻvų sukauptų ar pasiskolintų lëšu), filantropinès organizacijos, verslininkai, kuriems reikalingi specialistai, turintys tam tikrų žinių ir valstybè. Jei individas tikisi geresnio uždarbio dẻl to, kad turès atitinkamą išsilavinimą, jis skiria savo išteklius šiam išsilavinimui ịsigyti. Ištekliai gaunami kuo ịvairiausiai. Pirmiausias ir paprasčiausias - darbas ir taupymas. Sudètingesnis ir ilgalaikiškesnis -tèvų rūpinimasis savo vaikais, t.y., jų darbas ir taupymas. Išsiplètojusios rinkos salygomis atsiveria dar daugiau mechanizmų. Pinigai studijoms gali būti skolinami (šiuo atveju $\mathfrak{i}$ finansavimo mechanizmą ịsijungia bankai ir kiti skolintojai) arba sumokami kaip avansas už būsimą darbą (šiuo atveju i finansavimą itraukiamas darbdavys).

Daugiau nei pusé visų priimtų individų $\mathfrak{i}$ aukštąsias mokyklas patys moka už savo studijas, likusiems studijų mokesti padengia valstybė. 


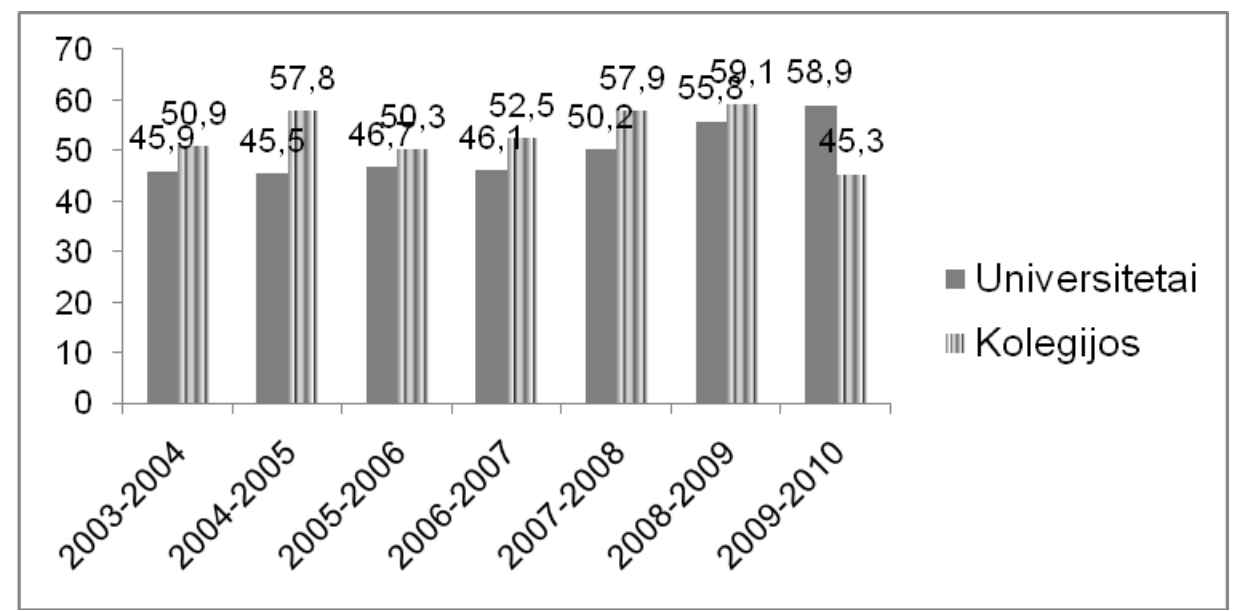

1 pav. İ universitetus ir kolegijas priimtų studentų, mokančių už studijas, dalis nuo bendro priimtų studentų Šaltinis: Statistikos departamentas prie LR Vyriausybès skaičiaus, proc.

Aukštasis išsilavinimas yra neabejotinai naudingas ne tik individui, bet ir valstybei. Valstybinis aukštojo mokslo finansavimas suteikia individui galimybę siekti aukštojo mokslo ir žinių, igyti darbo rinkai reikalingas kompetencijas. Tuo pačiu aukštojo mokslo finansavimas gali turèti ir neigiamą poveiki tiek individo, tiek valstybės požiūriu - jei individai, siekdami aukštojo mokslo finansavimo, pasirinks netinkamas studiju sritis. Valstybės biudžeto asignavimų aukštajam mokslui dalis, tenkanti vienam studentui 20092010 mokslo metais, siekè 8,1 tūkst. Lt. (2 pav.) Taigi jei individas, pasinaudojęs valstybès asignavimu, igis netinkamą specialybę, tai tiek individui, tiek ir valstybei šios investicijos bus nenaudingos ir neatsipirks, nes individas nedirbs darbo, atitinkančio jo kvalifikaciją. Tokiu atveju individo darbo užmokestis neaugs, valstybè nesurinks daugiau mokesčių.

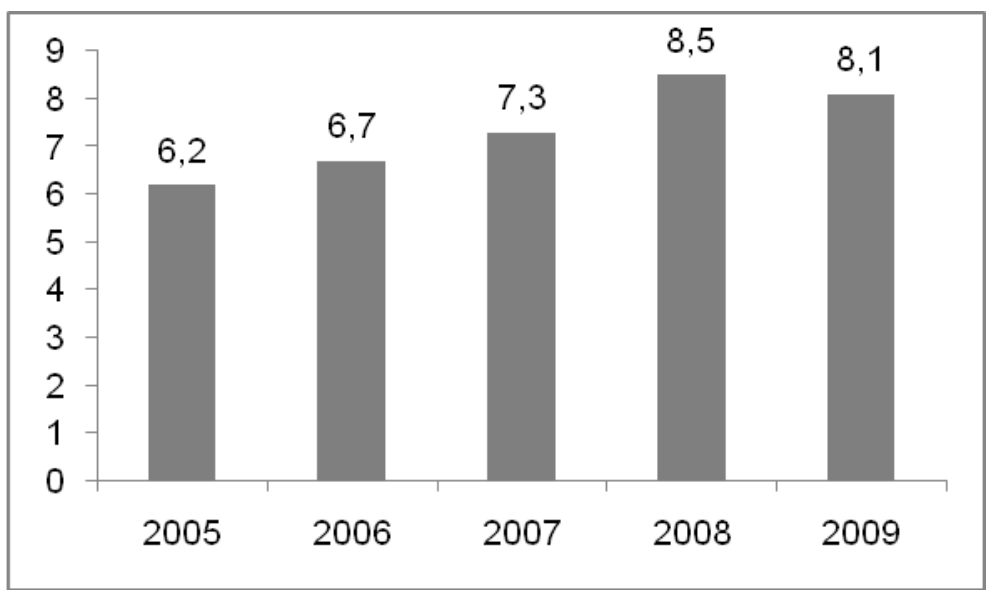

2 pav. Valstybės biudžeto asignavimų aukštajam mokslui išlaidos, tenkančios vienam studentui, tūkst. Lt Šaltinis: Statistikos departamentas prie LR Vyriausybès

Kitas labai aktualus klausimas, vertinant investicijų $i$ aukštaji išsilavinimą itaką valstybei - „protu nutekejjimas“, t.y., kvalifikuotos darbo jègos emigracija. Remiantis 1 lentelès duomenimis, 2003 m. emigravusių individu, igijusių aukštaji išsilavinimą, buvo 1,6 tūkst., o 2007 metais šis skaičius išaugo iki 3,1 tūkst. (išaugo beveik 2 kartus). Šios tendencijos rodo, kad kiekvienais metais emigruoja vis daugiau individų, igijusių aukštaji išsilavinimą.

1 lentelè. Emigrantai, igiję aukštaji ir aukštesnį išsilavinimą ir nedeklaravę išvykimo

\begin{tabular}{|l|c|c|c|c|c|}
\hline & $\mathbf{2 0 0 3}$ & $\mathbf{2 0 0 4}$ & $\mathbf{2 0 0 5}$ & $\mathbf{2 0 0 6}$ & $\mathbf{2 0 0 7}$ \\
\hline Emigrantai (16 m. ir vyresni), igiję aukštaji išsilavinima, tūkst. individu & 1,6 & 4,3 & 3,5 & 2,7 & 3,1 \\
\hline Palyginti su bendru emigrantų, nedeklaravusių išvykimo, skaičiumi, proc. & 14,7 & 26,4 & 12,6 & 20,8 & 25,8 \\
\hline
\end{tabular}

Šaltinis: Statistikos departamentas prie LR Vyriausybès 
Vertinant, kokią žalą ar naudą patiria valstybè, investuodama į aukštaji išsilavinimą, susiduriama su tokiomis problemomis:

- Duomenu trūkumas. Statistikos departamentas prie LR Vyriausybès nuo 2007 metu neturi duomenu apie emigrantus su aukštuoju išsilavinimu. Iki 2007 metu pateikiami tik duomenys apie emigrantus, kurie yra igiję aukštaji išsilavinimą, bet nėra deklaravę savo išvykimo.

- Duomenu vèlavimas.

Informacijos gavimo ir duomenų trūkumo problemos buvo sprendžiamos žemiau išdèstytais būdais:

- Trūkstami duomenys buvo prognozuoti pagal regresijos funkcijas;

- Valstybès investicijų praradimas dèl emigrantų su aukštuoju išsilavinimu vertinamas tik ịvertinant emigrantus, kurie igiję aukštaji išsilavinima, bet nedeklaruoja išvykimo.

Lietuvoje nėra svarbiausių kompetencijų, kurių reikia sėkmingam žinių ekonomikos funkcionavimui, nustatymo, kuris leistų visą mokymo procesą orientuoti ne i atskirų žinių kaupimą, o i tam tikrų kompetenciju ugdymą. Svarbu pažymèti, kad tos kompetencijos turètų būti išugdomos jau vidurinèje mokykloje, o aukštojoje mokykloje jos turètų būti tik tobulinamos. Aiškiu kompetencijų nustatymas ¡vairioms studiju pakopoms leistu galiausiai apibrèžti, ko darbo rinka turètų tikètis iš asmens, igijusio neuniversitetini aukštaji išsilavinimą, baigusio bakalauro, magistro ar doktorantūros studijas. Nustatant kompetencijas turetų aktyviai dalyvauti darbdavių atstovai.

2 lentelè. Valstybès lëšų, investuotu i a aukštaji išsilavinima, praradimas, dèl emigracijos

\begin{tabular}{|c|c|c|c|c|c|c|}
\hline & 2005 & 2006 & 2007 & 2008 & 2009 & 2010 \\
\hline $\begin{array}{l}\text { Valstybės ir savivaldybių biudžetų išlaidos švietimui: } \\
\text { aukštojo mokslo studijos, mln. litų }\end{array}$ & 898,6 & 965,7 & 1058,3 & 1259 & 1189,5 & 1337 \\
\hline Parengta specialistų (su aukštuoju išsilavinimu), individai & 38772 & 42117 & 42539 & 41876 & 43720 & 43853 \\
\hline $\begin{array}{l}\text { Valstybės biudžeto asignavimų aukštajam mokslui } \\
\text { išlaidos, tenkančios vienam studentui, tūkst. Lt }\end{array}$ & 6,2 & 6,7 & 7,3 & 8,5 & 8,1 & 9,04 \\
\hline $\begin{array}{l}\text { Emigrantai, igiję aukštaji išsilavinimą, bet nedeklaravę } \\
\text { išvykimo, tūkst. individų }\end{array}$ & 3500 & 2700 & 3100 & 3500 & 3900 & 4300 \\
\hline Valstybės finansuojamos I pakopos studijų vietos & 65612 & 63255 & 61209 & 57660 & 52994 & 47256 \\
\hline Valstybès finansuojamos koleginès studijų vietos & 55949 & 56297 & 60096 & 61383 & 56704 & 53297 \\
\hline $\begin{array}{l}\text { Valstybės finansuojamų koleginių ir I pakopos (bakalauro } \\
\text { studijų) vietų skaičius }\end{array}$ & 121561 & 119552 & 121305 & 119043 & 109698 & 100553 \\
\hline $\begin{array}{l}\text { Valstybės biudžeto asignavimų aukštajam mokslui } \\
\text { išlaidos, tenkančios visiems valstybės finansuojamų } \\
\text { koleginių ir I pakopos (bakalauro) studijų studentams, } \\
\text { tūkst. Lt }\end{array}$ & 753678,2 & 800998 & 885527 & 1011866 & 888554 & 908999,1 \\
\hline $\begin{array}{l}\text { Valstybės lèšu praradimas dėl emigracijos (,,protų } \\
\text { nutekéjimo“), tūkst. Lt }\end{array}$ & 21700 & 18090 & 22630 & 29750 & 31590 & 38872 \\
\hline $\begin{array}{l}\text { Valstybės lèšų praradimas dèl emigracijos („protų } \\
\text { nutekèjimo“), proc. }\end{array}$ & 2,88 & 2,26 & 2,56 & 2,94 & 3,56 & 4,28 \\
\hline
\end{tabular}

Atliktas valstybès lèšų, investuotų $\mathfrak{i}$ aukštaji išsilavinima, praradimo, dèl emigracijos tyrimas (2 lentelè) leidžia daryti išvadą, kad kiekvienais metai valstybè vis daugiau investuotų lèšų i švietimo sistemą praranda dèl „protų nutekèjimo“. 2005-2010 m. prarandamų lěšų skaičius išaugo 1,8 karto (pasiekè 4,28 proc.). Kadangi tyrimas buvo atliekamas ivvertinus tik emigrantų, igijusių aukštaji išsilavinimą, bet nedeklaravusių išvykimo, skaičių, tai šis valstybès investiciju neefektyvumas tikètina, yra didesnis. Atlikti empiriniai tyrimai parode, kad igytas išsilavinimas prisideda prie individo pajamų augimo. Investicijų $\mathfrak{i}$ žmogiškaji kapitalą grąža yra teigiama netgi ịvertinus patirtas tiesiogines ir netiesiogines išlaidas. Išsilavinusių individų pajamos yra aukštesnès už vidutines, o tai reiškia, kad valstybė surenka daugiau mokesčių. Norint Lietuvoje išlaikyti aukštos kvalifikacijos specialistus, būtina tobulinti tiek švietimo sistemą, tiek ir darbo rinką.

Atlikus investicijų $\mathfrak{i}$ aukštaji išsilavinimą neigiamo poveikio (nuostoliu) vertinimą būtina atlikti ir teigiamu poveikių (naudos) vertinimą. Vertinimas atliekamas apskaičiuojant valstybés investiciju i aukštaji išsilavinimą grąžos normą (ROR). 
3 lentelė. Investiciju grąžos norma (ROR) valstybei, $2010 \mathrm{~m}$.

\begin{tabular}{|l|r|}
\hline ROR valstybės iš koleginių studiju, proc. & $\mathbf{3 , 9 6}$ \\
\hline ROR valstybės iš universitetinių studiju, proc. & $\mathbf{1 5 , 5 5}$ \\
\hline
\end{tabular}

Lentelès duomenys rodo, kad ROR valstybès (universitetinio išsilavinimo) $>\mathrm{ROR}_{\text {valstybès }}$ (koleginio išsilavinimo). Tai leidžia daryti išvadas, kad valstybei labiau apsimoka subsidijuoti universitetines studijas, nei kolegines studijas. Universitetinių studijų grąžos norma keturis kartus didesnè, nei koleginiu studijų. Individas, igijęs aukštaji universitetini išsilavinimą uždirba daugiau, nei individas igijęs kolegini išsilavinimą. Negalima vienareikšmiškai teigti, kad koleginès studijos nėra efektyvios, nes vertinant valstybės investicijas į aukštaji išsilavinimą nėra įvertinami tokie faktoriai kaip asmeninès individų savybès, jų gebèjimai, nes sèkmingas įsitvirtinimas darbo rinkoje priklauso ne tik nuo aukštojo išsilavinimo igijimo, bet ir nuo individo asmeninių savybių.

\section{Išvados}

Išsilavinimas yra šiuolaikinės žinių ekonomikos plètros veiksnys, skatinantis ekonomikos augimą, nes didèja darbo produktyvumas, darbo našumas, greičiau isisavinami technologiniai pokyčiai (naujos technologijos). Valstybèje, kurioje skiriamos didesnès investicijos i žmoniškaji kapitalą, intensyviau auga žmogui tenkantis bendrasis vidaus produktas.

Atliktas valstybės lèšų, investuotų i aukštaji išsilavinima, praradimo, dėl emigracijos tyrimas atskleidè, kad kiekvienais metai valstybė vis daugiau investuotų lěšu i $\mathfrak{i}$ švietimo sistemą praranda dèl „protu nutekejjimo“. 2005-2010 m. prarandamų lëšų skaičius išaugo 1,8 karto (pasiekė 4,28 proc.).

Apskaičiuota valstybès investicijų i aukštaji išsilavinimą trumpalaikè grąžos norma (ROR) parodè, kad $\mathrm{ROR}_{\text {valstybès }}$ (universitetinio išsilavinimo) $>\mathrm{ROR}_{\text {valstybès }}$ (koleginio išsilavinimo) $(15,55 \%>3,96 \%$ ). Tai rodo, kad valstybei naudingiau subsidijuoti universitetines studijas, nei kolegines studijas.

Lietuva, turẻdama susiformavusią žinių vertinimo kultūrą, nepakankamai išnaudoja savo žiniu išteklius - žmones, švietimo sistemas, mokslininkus, verslininkus ir t.t., taip prarasdama dali galimybiu konkuruoti tarptautiniu mastu, o kartu potencialias ekonomikos ir pajamų augimo galimybes.

\section{Literatūra}

1. Bagdanavičius, J. (2009). Žmogiškasis kapitalas. Vilnius: Vilniaus pedagoginio universiteto leidykla.

2. Baier, S.; Dwyer, G.; Tamura, R. (2006). How important are capital and total factor productivity for economic growth? Economic Inquiry, 44(1), 23-50.

3. Becker, G. (1962). Investment in human capital: A theoretical analysis. Journal of Political Economy, 70, 9-49.

4. Becker, G. (1964). Human capital. New York, NY: National Bureau of Economic Research.

5. Čekanavičius, L.; Kasnauskienè, G. (2009). Too High or Just Right? Cost-Benefit Approach to Emigration Question. Inžinerinè Ekonomika-Engineering Economics(1), 28-36.

6. Daugèlienė, R.; Marcinkevičienė, R. (2009). Brain Circulation: Theoretical Considerations. Inžinerinè EkonomikaEngineering Economics(3), 49-57.

7. European Commission. (2005). The Returns to Various Types of Investment in Education and Training. London Economics. Final Report To EC DG EAC. Prieiga per internetą: http://ec.europa.eu/education/policies/2010/studies/invest05_en.pdf.

8. Globerman, S.; Shapiro, D. (2002). Global foreign direct investment flows: The role of governance infrastructure. World Development, 30(11), 1899-1919.

9. Haveman, R.; Bershadker, A.; Schwabish, J. (2003). Human capital in the United States from 1975 to 2000. Kalamazoo, MI: W.E. Upjohn Institute for Employment Research.

10. Hazelkorn, E.; Huisman, J. (2008). Higher Education in the 21st Century - Diversity of Missions. Higher Education Policy, Vol. 21, No 2, June, 147-150.

11. Johnes, G., Johnes, J. (2004). International Handbook on the Economics of Education. USA: Edward Elgar Publishing Limited.

12. Kazlauskaite, R., \& Buciuniene, I. (2008). The Role of Human Resources and their Management in the Establishment of Sustainable Competitive Advantage. Inzinerine Ekonomika-Engineering Economics(5), 78-84.

13. Kendrick, J. (1976). The formation and stock of total capital. New York: Columbia University Press. 
14. Liepe, Z., \& Sakalas, A. (2008). The Three-loop Learning Model Appliance in New Product Development. Inzinerine Ekonomika-Engineering Economics (3), 73-80.

15. Makštutis, A. (2007). The problems of development of national state. Journal of Business Economics and Management, 8(1), 63-68.

16. Mankiw, G.; Romer, D.; Weil, D. (1992). A contribution to the empirics of economic growth. Quarterly Journal of Economics, 152, 407-437.

17. Melnikas, B. (2008). The Knowledge-Based Economy in the European Union: Innovations, Networking and Transformation Strategies. Transformations in Business \& Economics 7(3), 170-192

18. Mincer, J. (1958). Investment in human capital and personal income distribution. The Journal of Political Economy, 66(4), 281-302.

19. Mincer, J. (1974). Schooling, experience and earnings. National Bureau for Economic Research. New York: Columbia University Press.

20. Mingat, A.; Tan, J. P. (1996). The Full Social Returns to Education: Estimates Based on Countries Economic Growth Performance. World Bank.

21. Noorbakhsh, F.; Paloni, A.; Youssef, A. (2001). Human capital and FDI inflows to developing countries: New empirical evidence. World Development, 29(9), 1593-1610.

22. Psacharopoulos, G. (1995). The Profitability of Investment in Education: Concepts and Methods.

23. Schultz, T. (1971). Investment in human capital. New York: NY: The Free Press.

24. Sedziuviene, N., \& Vveinhardt, J. (2009). The Paradigm of Knowledge Management in Higher Educational Institutions. Inzinerine Ekonomika-Engineering Economics (5), 79-90.

25. Seniūnaitè, L. (2002). Žmogiškojo kapitalo itaka šalies vystymuisi. Žmogiškojo kapitalo formavimo problemos. Ekonomika ir vadyba. 4 knyga. Kaunas: Technologija.

26. Tamašauskienè, Z.; Šileika, A.; Smolenskiené, F. (2008). Lietuvos aukštojo mokslo finansavimo problemos ir ju sprendimo kryptys. Ekonomika ir vadyba: aktualijos ir perspektyvos, 1(10), 175-185.

27. Wößmann, L.; Schütz, G. (2006). Efficiency and Equity in European Education and Training Systems. European Expert Network on Economics of Education. 